\title{
Far-Field Aftershocks of the 1906 Earthquake
}

\author{
by Don W. Steeples and Dan D. Steeples
}

\begin{abstract}
During the $24 \mathrm{hr}$ following the great San Francisco, California, earthquake of 18 April 1906, separate seismic events were felt at Paisley, Oregon; Phoenix, Arizona; Los Angeles, California; and Brawley, California (MM IX). Using probability theory, we show that the occurrence of felt earthquakes in each of these widespread locations on the same day would constitute a rare event. Rates of feltearthquake occurrences over a 9-yr period from 1897 to 1906 were determined for the four different regions that experienced earthquakes within $24 \mathrm{hr}$ after the 1906 event. We modeled the likelihood of occurrence of these aftershocks in the spirit of the "ball-in-the-box" probability problem, and the results indicated a very high probability that the aftershock zone of the great earthquake extended at least $500 \mathrm{~km}$ beyond the extent of ground breakage, implying a disturbance of the stress field over an area at least two to three times longer than the fault break itself.
\end{abstract}

Introduction

Separate earthquakes were felt at Paisley, Oregon; Phoenix, Arizona; Los Angeles, California; and Brawley, California (MM IX) during the 24-hr period following the San Francisco, California, earthquake of 18 April 1906 (Fig. 1 ; Table 4). An analysis of these events in the context of the seismicity patterns that led up to the 1906 event suggests that one or more of the events was related to the $M 8.3$ shock that occurred near Olema, California, at 5:12 a.m. local time on 18 April 1906.

The findings reported here were first presented more than a decade ago by Steeples and Steeples (1981). We suggest that these results have since taken on additional significance in light of the remote seismicity triggered by the Landers, California, earthquake of 28 June 1992, as reported by Reasenberg et al. (1992) and Hill et al. (1993).

The aftershock zones of great earthquakes tend to define the slip area of the affected fault. Thus, a large aftershock area would be likely for an earthquake that broke ground for at least $430 \mathrm{~km}$. In fact, we would expect the aftershock zone to extend beyond the area of surface breakage for several tens of kilometers at either end. We might not expect the aftershocks to extend from Oregon to Mexico, however, particularly when we refer to true aftershocks in the strictest sense, i.e., when they are associated directly with changes brought about by the stress and strain induced by the 1906 earthquake itself.

The aftershock tables in the Report of the State Earthquake Investigation Commission on the 1906 Earthquake (Lawson et al., 1908) indicate that the 1906 earthquake may have triggered one or more earthquakes several hundred kilometers away from the zone of breakage. In particular, shocks were reported in Paisley, Oregon, and Brawley, Cal- ifornia, within $21 \mathrm{hr}$ of the major earthquake. Brawley is just across the border from Mexicali, Mexico, and Paisley is about $120 \mathrm{~km}$ northwest of the junction of Oregon, California, and Nevada (Fig. 1). The total distance from Paisley to Brawley is about $1300 \mathrm{~km}$, which is too far to be within the main aftershock zone. An earthquake was reportedly felt in Phoenix, Arizona, about 30 min after the mainshock on 18 April, and an intensity-III shock occurred in Los Angeles about $7 \mathrm{hr}$ after the mainshock.

We analyzed historical earthquake data from the period 1897 to 1906 (McAdie, 1907) to establish the likelihood that each of these earthquakes would occur independently. We then calculated the probability that these earthquakes were unrelated to the mainshock at Olema (near San Francisco) on the morning of 18 April 1906 . We assumed that the reported far-field aftershocks had epicenters near the specific localities in which they were felt or where the intensity was greatest (in the case of the Brawley shock). These events may have been triggered by or associated with the mainshock. An alternative hypothesis is that these shocks, which were widely scattered geographically, were random phenomena that would have occurred even without the 8.3-magnitude Olema event. A third possibility is that these reports were "outlier" felt reports of strong aftershocks nearer the mainshock, but this option can be discounted by inspecting closely the relatively large list of felt reports from the principal aftershocks in Lawson et al. (1908).

\section{Data}

Healy et al. (1968) performed a statistical treatment of a swarm of earthquakes near a waste-disposal well near Den- 


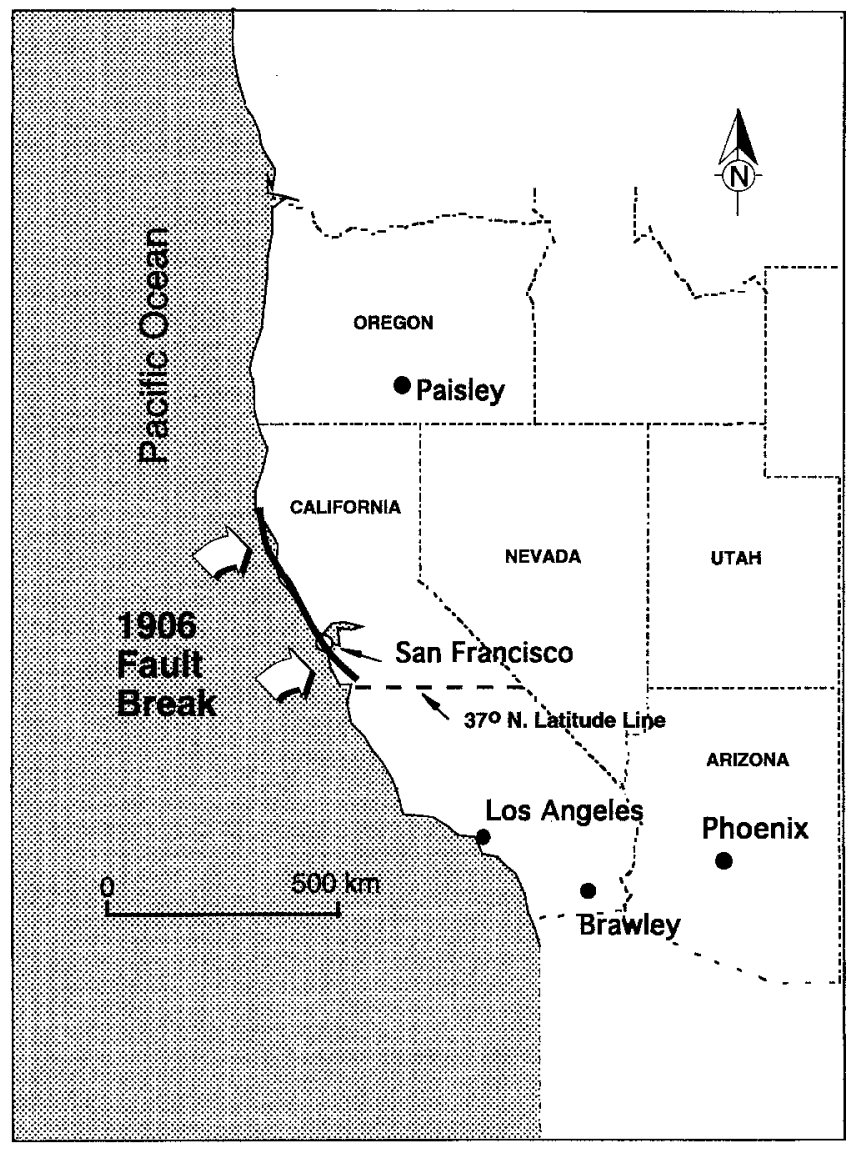

Figure 1. Separate earthquakes were felt in Paisley, Oregon; Phoenix, Arizona; and Los Angeles and Brawley, California, during the 24-hr period following the 1906 San Francisco earthquake. The $37^{\circ} \mathrm{N}$ latitude line serves to separate northern California from southern California. Fault-breakage line based on Lawson et al. (1908).

ver, Colorado. They divided the state of Colorado into areas corresponding to the size of the swarm of epicenters and estimated the likelihood that a swarm would be initiated within a specified time period anywhere in the state. They then showed that the chances that a swarm would occur near the waste-disposal well, but that would be unrelated to well injections, was about one in several million.

In the present article, we adopted a similar approach. We used the "ball-in-the-box" analogy from probability theory to examine the possible relationships among these farfield aftershocks. We calculated the probability that each aftershock location would independently undergo an earthquake during a random 24-hr period. Using combinatorial theory, we then analyzed the probability that all of these farfield aftershocks were independently random events.

To establish probabilities for each area, we used the catalog of McAdie (1907), made the following assumptions, and used the procedures outlined below:

1. The West Coast area was subdivided into four regions, and earthquakes from McAdie (1907) were assigned into their respective regions of occurrence. The regions are Oregon, California north of $37^{\circ}$, California south of $37^{\circ}$, and Arizona.

2. Earthquakes in each region are independent of earthquakes in other regions.

3. Earthquakes are random in time.

4. Earthquake swarms count as one event.

5. Clearly defined events and their aftershock sequences from McAdie count as one event.

6. The catalog of events by McAdie (1907) for the period 1897 to 1906 is complete and homogeneous.

We know that this last assumption is in error, but we do not know by how much. To test the effects of incompleteness, we ran our calculations two more times under the assumption that the catalog only listed one-half and one-quarter, respectively, of the events that occurred. This test is justified to some degree by the fact that complete newspaper coverage of earthquakes on 18 April is likely, but incomplete reporting is likely for the 9-yr period prior to 1906. Cataloged earthquakes from Owens Valley, California, and Nevada were omitted from the process for two reasons. First, no aftershocks were reported there immediately on or near 18 April 1906, and second, if aftershocks had been reported there, the area east of the Sierra would have been considered independently.

The number of felt earthquakes reported for each area from 1897 to 1906 is shown in Table 1.

The probability $\left(P_{i}\right)$ of feeling one or more earthquakes in any one of these areas $(i)$ on a random day during the sample time should be given by

$$
P_{i}=1-\left(\frac{N-1}{N}\right)^{n_{i}}
$$

where $N=$ number of days in the sample and $n_{i}=$ number of felt earthquakes in area $i$.

Many diverse situations are probabilistically equivalent to the scheme of randomly placing $k$ balls into $n$ cells. Here, $k$ corresponds to $n_{i}$, the number of earthquakes felt in area $i$, and $N$ corresponds to $N=3394$ days in the sampling period. Now, $[N /(N-1)]^{n_{i}}$ is the probability that on any given day, area $i$ does not undergo an earthquake. Thus, one minus this value is the probability that area $i$ will experience

Table 1

Number of Felt Earthquakes Reported between 1 January 1897 and 17 April 1906 (McAdie, 1907)

\begin{tabular}{lc}
\hline State & Reported Earthquakes \\
\hline Arizona & 3 \\
California (northern) & 345 \\
California (southern) & 192 \\
Oregon & 5 \\
\hline
\end{tabular}


at least one earthquake. For more information on these types of probability problems, see Feller (1968).

Using the data from Table 1, and the fact that 3394 days of reports are included in McAdie's catalog, we calculate $P_{i}$ for individual areas, as shown in Table 2.

Table 2 gives the estimated probability of feeling at least one earthquake in each of the areas in a randomly selected 24-hr period during the 3394 days of McAdie's catalog prior to 18 April 1906.

Assuming independence, the probability that an observer in each of the four areas would experience an earthquake whose epicenter was in his or her own area on a randomly selected day (or 24-hr period) is the product of the probabilities for each individual area. Let $P^{*}$ be this probability; then

$$
\begin{aligned}
P^{*} & =P_{1} \cdot P_{2} \cdot P_{3} \cdot P_{4} \\
& =7 \times 10^{-9}
\end{aligned}
$$

Equation (2) also has another interpretation. It represents the probability that each of the defined study areas would record at least one event in a particular 24-hr period.

Though equation (2) gives the probability for any particular 24-hr period, the more interesting question is, what is the probability of ever observing four or more felt earthquakes (at least one in each area) in a single day during the 3394-day test period? Using the Poisson approximation to the binomial distribution, this value is given by

$$
\begin{aligned}
1- & \frac{e^{-P^{*} N}\left(P^{*} N\right)^{0}}{0 !} \\
& =2.38 \times 10^{-5} .
\end{aligned}
$$

To the extent that our assumptions are valid, the probability that the events in Table 3 were random and unrelated phenomena is therefore smaller than $2.38 \times 10^{-5}$. This means that the odds are about 50 thousand to 1 that two or more of the earthquakes in Table 3 are related, i.e., that these earthquakes are not random phenomena, provided that the assumptions are all valid.

One of our assumptions was that the catalog of earthquakes is complete; however, the earthquake catalog from 1897 to 1906 is almost certainly incomplete. We examined the ramifications of the catalog's being homogeneously $50 \%$ and $25 \%$ complete, respectively. When the number of felt earthquakes is doubled for all areas (i.e., assuming only half the actual earthquakes are listed in the catalog), we find

$$
P^{*}=1.02 \times 10^{-7}
$$

and

$$
1-\frac{e^{-P^{*} N}(P * N)}{0 !}=0.000347
$$

Table 2

Estimated Daily Probability of Felt Earthquakes by Region

\begin{tabular}{ll}
\hline State or Area & Estimated Earthquake Probability \\
\hline Arizona & $P_{1}=1-\left(\frac{3393}{3394}\right)^{3}=0.0009$ \\
Northern California & $P_{2}=1-\left(\frac{3393}{3394}\right)^{345}=0.0967$ \\
Southern California & $P_{3}=1-\left(\frac{3393}{3394}\right)^{192}=0.0550$ \\
Oregon & $P_{4}=1-\left(\frac{3393}{3394}\right)^{5}=0.0015$ \\
\hline
\end{tabular}

Table 3

18 April 1906 Earthquakes and Their Associated Probabilities of Occurrence

\begin{tabular}{crlc}
\hline \multicolumn{1}{c}{ Date } & \multicolumn{1}{c}{ Time } & \multicolumn{1}{c}{ Locality } & Probability of Occurrence \\
\hline 18 April & 5:12 a.m. & Olema, California & 0.0967 \\
18 April & $5: 48$ a.m. & Phoenix, Arizona & 0.0009 \\
18 April & $12: 31$ p.m. & Los Angeles, California & 0.0550 \\
18 April & $4: 30$ p.m. & Brawley, California & 0.0550 \\
19 April & $1: 30$ a.m. & Paisley, Oregon & 0.0015 \\
\hline
\end{tabular}

which figures out to about 2880 to 1 that one or more earthquakes are related. Viewed another way, this says that a similar combination of felt earthquakes might be expected once in $26,800 \mathrm{yr}$, on average, if the earthquake catalog is $50 \%$ complete.

When the number of felt earthquakes is quadrupled for all areas,

$$
P^{*}=1.39 \times 10^{-6}
$$

and

$$
1-\frac{e^{-P^{*} N}(P * N)^{0}}{0 !}=0.0047
$$

Hence, even if the catalog is too low by a factor of 4 in each of the areas for which probability calculations were made, a similar series of earthquakes could be expected on the average of once in 722,000 days or about once in 1978 years.

\section{Discussion and Conclusions}

The foregoing calculations, though approximate and open to adjustment because of inherent uncertainties in the number of felt earthquakes, show that the far-field aftershock zone for the 1906 earthquake extended at least to Los Angeles or Brawley and possibly to Phoenix, Arizona, and/or Paisley, Oregon. This would seem to indicate that the 1906 earthquake modified the stress field for about $500 \mathrm{~km}$ beyond the point at which ground breakage ceased. The observations 
Table 4

Events of 18-19 April 1906

\begin{tabular}{lcccc}
\hline & & & & \\
Number & & \\
of Events \\
Area & Time & Date & Intensity & Locality \\
\hline Northern California & $5: 12$ a.m. & 18 April & XI & San Francisco, California \\
Arizona & $5: 48$ a.m. & 18 April & I-II & Phoenix, Arizona \\
Southern California & $12: 31$ p.m. & 18 April & III & Los Angeles, California \\
Southern California & $4: 30$ p.m. & 18 April & IX & Brawley, California \\
Oregon & $1: 30$ a.m. & 19 April & I-II & Paisley, Oregon \\
\hline
\end{tabular}

reported here take on new significance in light of the observations of increased earthquake activity in areas several hundred kilometers from the Landers earthquake of 1992 (Reasenberg et al., 1992; Hill et al., 1993).

\section{Acknowledgments}

This manuscript was first prepared by Don Steeples in 1973 as a term paper for a course entitled "The 1906 San Francisco Earthquake" offered by Professor David Boore at Stanford University. Professor Boore was not particularly impressed with the findings at that time, but the authors wish to express their appreciation to him for encouraging the submission of this slightly revised version for publication. Reviews by two anonymous reviewers were most helpful in focusing the article.

\section{References}

Feller, W. (1968). An Introduction to Probability Theory and Its Applications, Vol. 1, 3rd ed., John Wiley and Sons, Inc., New York.

Healy, J. H., W. W. Rubey, D. T. Griggs, and C. B. Raleigh (1968). The Denver earthquake, Science 61, 1301.

Hill, D. P., P. A. Reasenberg, A. Michael, W. J. Arabaz, G. Beroza, D. Brumbaugh, J. N. Brune, R. Castro, S. Davis, D. DePolo, W. L. Ellsworth, J. Gomberg, S. Harmsen, L. House, S. M. Jackson, M. J. S. Johnston, L. Jones, R. Keller, S. Malone, L. Munguia, S. Nava, J. C. Pechmann, A. Sanford, R. W. Simpson, R. B. Smith, M. Stark, M. Stickney, A. Vidal, S. Walter, V. Wong, and J. Zollweg (1993). Seismicity remotely triggered by the magnitude 7.3 Landers, California, earthquake, Science 260, 1617-1623.
Lawson, A. C., with G. K. Gilbert, H. F. Reid, J. C. Branner, H. W. Fairbanks, H. O. Wood, J. F. Hayford, A. D. Baldwin, F. Omori, A. O. Leuschner, G. Davidson, F. E. Matthes, R. Anderson, G. D. Louderback, R. S. Holway, A. S. Eakle, R. Crandall, G. F. Hoffman, G. A. Warring, E. Hughes, F. J. Rogers, A. Baird, and many others (1908). The California earthquake of April 18, 1906, Report of the State Earthquake Investigation Commission, Carnegie Institution of Washington, Washington, D.C., Pub. No. 87, I, 641 pp. (I and II).

McAdie, A. G. (1907). Catalogue of earthquakes on the Pacific coast 1897 to 1906 , Smithsonian Institution Publication No. 1721, pp. 5-55.

Reasenberg, P. A., D. P. Hill, A. J. Michael, R. W. Simpson, W. L. Ellsworth, S. Walter, M. Johnston, R. Smith, S. J. Nava, W. J. Arabasz, J. C. Pechmann, J. Gomberg, J. N. Brune, D. DePolo, G. Beroza, S. D. Davis, and J. Zollweg (1992). Remote seismicity triggered by the M7.5 Landers, California earthquake of June 28, 1992: $\operatorname{EOS} 73$, no. 43, 392.

Steeples, D. W. and D. D. Steeples (1981). Far-field aftershocks of the 1906 Francisco Earthquake? (abstract), Earthquake Notes 52, no. 1, 11.

Department of Geology

The University of Kansas

Lawrence, Kansas 66045-2124

(D.W.S.)

Steeples and Associates Consulting Statisticians

107 South West St. \#262

Alexandria, Virginia 22314

(D.D.S.)

Manuscript received 18 May 1993. 